DOI 10.18551/rjoas.2019-09.13

\title{
STRUCTURAL CAPITAL MEDIATES HUMAN CAPITAL EFFECT BASED ON ASTA BRATA AGAINST FINANCIAL PERFORMANCE OF PEOPLE'S RURAL BANKS IN BALI
}

\author{
Mahanavami G. Ayu*, Wiksuana I G.B., Purbawangsa I.B. Anom, Rahyuda Henny \\ Faculty of Economics and Business, Udayana University, Bali, Indonesia \\ *E-mail: mahanavami09@yahoo.co.id
}

\begin{abstract}
The purpose of this study is to examine and explain the effect of human capital and structural capital on the financial performance of Rural Credit Banks in Bali, both in direct and indirect relationships. This study uses a mixed research design, a research method that combines quantitative and qualitative research designs. The population in this study is conventional BPRs in the Province of Bali, totaling 136 BPRs (Bank Indonesia, 2016), with a sample of 60 BPRs in Bali. The unit of analysis is 60 BPR leaders. Quantitative analysis based on multivariate analysis uses structural equation modeling or SEM (structural equation modeling) with a variance based or component based approach called PLS (partial least square). The results of this study indicate that: Human capital has no significant effect on the financial performance of Rural Credit Banks in Bali Province; Human capital and structural capital have a significant positive effect on the financial performance of Rural Credit Banks in Bali Province; Structural capital is able to fully mediate the influence of human capital on the financial performance of Rural Credit Banks in Bali. The novelty of this research are 1) examining intangible asets, namely human capital and structural capital on BPR financial performance in Bali, 2) human capital in this study is to explore leadership based on local Balinese concepts called Astabrata leadership. Some limitations of research and suggestions for further research are as follows: (a) Behavioral research is vulnerable to bias, so it needs to be tested in the future; (b) Results cannot be disputed because they are only carried out in the banking sector, namely BPR, so a comparative test is needed between BPRs with commercial banks, cooperatives or LPDs in Bali.
\end{abstract}

\section{KEY WORDS}

Structural capital, human capital, asta brata, financial performance.

Rural Bank (BPR) is a banking company that has different characteristics compared to commercial banks. The existence of rural banks is specifically intended to reach people from economically weak groups and small entrepreneurs both in rural and urban areas. In other cases, BPRs tend to adopt simpler service mechanisms, higher interest rates, and be more proactive in looking for customers compared to commercial banks. It is important to focus on intangible assets that are embedded in the know-how and knowledge of employees, databases, information technology, operating processes, customer relations, brands, trust, and culture (Andriessen, 2004; Kaplan, 2010). An organization needs uniqueness because competition becomes increasingly global and intense (Andriessen, 2004). The uniqueness that comes from intangible assets will not be easily imitated by other competitors. Khalique et al (2011), states that in a knowledge-based economy, the contribution of intangible assets is greater than tangible assets. Titko et al (2015) states that the performance of the banking sector is shown by the ratio of profitability: return on assets (ROA), return on equity (ROE), net costs and revenue as a percentage of total assets and net interest margin (NIM).

The banking business in Indonesia has not used intellectual capital effectively as expected (Ulum, 2008). Such pressures on organizational knowledge, both in terms of resources within an organization heavily dependent on external networks, have pushed entities into public awareness of the idea of Intellectual Capital. Intellectual capital (hereinafter abbreviated as IC) includes knowledge that comes from the company's workforce, from company competencies, and from relationships and interactions between 
organizations and external parties such as clients, partners, and suppliers.

Human capital as a key driving factor (driver) of all values born in innovation and spread throughout the organization / company in the form of individual employee capacity to act in various situations (Christa, 2011). The empirical study of Asiaei and Jusoh (2015) which concluded that human capital has a positive effect on company performance. Ritonga and Andriyanie (2011) states that human capital has a significant effect on company performance as measured by earnings per share of companies incorporated in LQ45. The results of the study contradict with Cabrita et al (2009), which states that human capital has no significant positive effect on company performance, Hashim et al (2015) which states that human capital is not significant on company performance. The existence of a research gap or differences in findings creates a gap to review the relationship.

Sangkala (2006) states that in addition to the structure / dimensions of the organization, leadership style also determines the form of relationships that take place within the company / organization, determining how human capital is given sufficient space to conduct knowledge and innovation or value creation activities for the company. The success of knowledge management in organizations depends on the leadership style. The need to explore the cultural heritage of past leadership philosophies that have the potential to be professionally developed in the present. Then it needs to be reviewed and maintained moral values which are sourced from the nation's own view of life, to bring up a group of leaders who have good character, personality and high moral responsibility (Kartono, 2014: 3). The Asta Brata leadership model based on local wisdom values is seen as able to move the BPR director to improve his financial performance.

The human capital variable in this study uses the Asta Brata leadership concept. The concept of Asta Brata's leadership refers to the concept of leadership in the Ramayana story, which was composed by the great Indonesian poet in ancient times namely Mpu Yogiswara, in 925 AD. Structural capital in organizations includes databases, organizational structures, manual processes, strategies, routines and policies (Bontis, et al, 2000). Empirical studies of structural capital on performance are carried out by Cabrita et al (2009); Shabarati et al (2010); Sayad and Pourmohammadi (2014); Luminitas (2016) which concluded that structural capital has a significant effect on performance. In contrast to the findings of Asiaei and Jusoh (2015) that structural capital has no significant effect on performance. Hariyanto and Hermawan's research results (2015) showed that structural capital had no effect on business performance in the pharmaceutical industry in East Java. The existence of a research gap or differences in findings creates a gap for researchers to review the relationship.

The novelty of this research is first, to examine intangible asets, namely human capital and structural capital on BPR financial performance in Bali so that they will use perception data. Research in the field of financial management, in general, examines physical capital (tangible assets) with ratio data. Second, human capital in this research is exploring leadership based on local Balinese concepts as leadership concepts that are maintained to improve financial performance. Human Capital in this study is a unique local values about the ethics of leadership in Bali, called Astabrata leadership, leadership is measured based on the perception of leadership, whether the leadership in the leadership process has referred to eight leadership qualities to improve employee welfare. The purpose of this study is to examine and explain the effect of human capital on the financial performance of Rural Credit Banks in Bali, to test and explain the effect of human capital on structural capital in Rural Credit Banks in Bali, to test and explain the effect of structural capital on the financial performance of Credit Banks People in Bali, to test and explain the role of structural capital mediating the relationship between human capital and the financial performance of the Rural Credit Bank in Bali.

\section{LITERATURE REVIEW}

Resources Based Theory/Resources Based View (RBV). Initial thinking about the view which states that the company is a collection of various resources was pioneered by Penrose 
(1959). The thought of heterogeneity of resources is what then becomes the basis of resources-based theory. Wernerfelt (1984) rebuilt Penrose's (1959) thinking by suggesting that strategic action requires a specific set of physical, financial, human or organizational resources, and thus competitive advantage is determined by its ability to obtain and maintain resources.

Barney (1991) shows a more concrete and comprehensive framework for identifying the characteristic needs of the company's resources in order to produce possible competitive advantages. These characteristics include whether resources are valuable (in the sense that companies take advantage of opportunities and or neutralize threats in the corporate environment), these resources are scarce among current and potential competitors, cannot be imitated, and cannot be replaced (Barney, 1991). According to the RBV, intellectual capital meets the criteria as a unique resource that is able to create a company's competitive advantage so as to create value for the company. Value in question is the better performance in the company.

Intellectual Capital (IC). Some researchers express the definition of intellectual capital as follows: Intellectual capital is a term given to combine intangible assets from markets, intellectual property, infrastructure and human centers that make a company function (Brooking, 1996); Intellectual capital is intellectual material (knowledge, information, intellectual property, experience) that can be used to create wealth. This is a power of collective or effective set of knowledge (Stewart, 1997); Edvinsson and Malone (1997) in Suryaningsih and Januarti (2012), classify company ICs consisting of human capital (HC) and structural capital (SC). $\mathrm{HC}$ is defined as knowledge qualifications, and employee skills while SC is the knowledge the company has. Structural capital includes the production process, information technology, customer relations, research and development. Intellectual capital can be interpreted as shares or capital based on knowledge owned by the company. This is also the end result of the process of transformation of knowledge or knowledge itself that is made in the form of assets or intellectual property of companies.

Human Capital. Evaluation of financial performance uses more physical resources (tangible assets). Measurement of company performance from a financial perspective is very accurate, but actually the basis for driving the financial value is human capital with all the knowledge, ideas and innovations it has (Mayo, 2000). In addition, human capital is also the core of a company.

Human capital in this study is based on Asta Brata leadership, Asta Brata leadership refers to eight leadership qualities to improve employee welfare (Sidharta, 2009; As'ad, 2011; Wirata, 2011; Iswachidah, 2012; Karyadi, 2013; Dasi Astawa and Sedana, 2017), namely: Indra Brata (welfare), Yama Brata (justice), Surya Brata (responsibility), Candra Brata (calmness), Bayu Brata (prioritizing employees), Kuwera or Danan Brata (prosperity), Waruna Brata (overcoming suffering and illness), Agni Brata (employee mobilizer). In this study, leadership is measured based on the perception of the leader, whether the leader in the leadership process has referred to eight leadership traits to improve employee welfare (Asta Brata).

Successful leaders are able to anticipate change and take advantage of opportunities strongly, motivate followers to achieve high levels of productivity, improve poor performance, and encourage organizations to achieve their goals (Dharmanegara et al, 2013). If classified into Yukl's classification (2010), the teachings of Asta Brata's leadership can be classified into a trait approach, referring to the qualities that leaders must possess.

Structural Capital. Structural capital arises from organizational processes and values, which reflect the internal and external focus of the company, plus the development and renewal of values for the future. If an organization has a bad system and procedure in carrying out its activities, overall intellectual capital will not reach its fullest potential (Bontis, 1998). Organizations with overall structural capital will have a sportsmanlike culture that allows individuals to try new things, learn them, and be prepared to fail. Structural capital is a critical link that allows intellectual capital to be measured at the level of organizational analysis (Bontis, et al, 2000).

Financial performance. In formal control systems performance measures include 
financial and non financial measures (Fisher, 1998). Financial size actually shows various actions that occur outside the financial sector. The increase in financial return is a result of various operational performance which include increasing consumer confidence in the products produced by the company, increasing cost effectiveness of internal business processes used by the company to produce products and increasing productivity and employee commitment, so that if a company aims to obtain financial performance, then the company should be able to motivate its employees from a non-financial perspective, because in that perspective there are the real drivers of long-term financial performance.

The description proves that the driver of a company's performance has changed. The shift from tangible assets to a new set of performance drivers creates difficult challenges for companies, managers and investors. One thing that is critical of corporate investors and stakeholders is the challenge of relevance, timeliness, reliability, consistency and comparability of information and its effect on the ability to measure the true value of companies in the new economy. In a new economy, there is a greater risk that organizations will not have the information they need to make strategic, operational and financial decisions. Current measurement and reporting systems cannot capture the emergence of sources of value and do not reflect the entire way companies create or eliminate value in a new economy (Ferrier \& McKenzie, 2004).

Research Conceptual Framework. This research is a causality research developed based on intellectual capital theory and financial performance. Human capital in this research was informed by the concept of Balinese local wisdom, namely Asta Brata's leadership. Indicators of each dimension are carried out through a qualitative approach, namely Indepth Interview. Structural capital is reflected in 3 dimensions, namely organizational culture, intellectual property and organizational processes. The bank's financial performance is reflected in the Minimum Capital Requirement (KPMM), cash ratio, Loan to Deposit Ratio (LDR), Return on Assets (ROA), Operational Income Operating Costs (BOPO) and Non Performing Loans (NPL).

Research Hypothesis. The emphasis of human capital is more on the role of human capital, where humans as the main component of the most dominant determine the performance of an organization both business and nonbusiness, in addition to structural capital, relational capital and social capital. Bontis et al, (2000) stated that human capital is the fresh blood of intellectual capital and at the same time is a key factor in the success of a company's business.

Research related to Human Capital and Financial Performance was conducted by several researchers, including Sharabati et al (2010) examining the relationship between Human Capital and business performance in 15 companies registered with the Jordanian Association of Pharmaceutical Manufacturers (JAPM). The results found that Human capital had a significant positive effect on business performance. Empirical studies of human capital variables based on employee perspectives were conducted by Chen et al (2014), Soheyli and Nayebzadeh, (2014), Asiaei and Jusoh (2015) which concluded that human capital had a positive effect on company performance.

Based on previous empirical studies, human capital will have a positive effect on financial performance. Thus the research hypothesis was formulated as follows:

Hypothesis 1: human capital has a positive effect on financial performance.

Effect of Human Capital on Structural Capital. Within companies, especially those based on knowledge, human capital is the most important resource. These resources are the dominant costs in the company's production process. Without these resources, the company will lose its activities. Tacit knowledge available to employees is a source of innovation and renewal strategy. Employee creativity and intelligence can change practices and think of innovative solutions to a problem. This will further improve or improve company knowledge (structural capital) such as organizational routines, procedures, systems, culture, databases and so on.

Bontis (1998), conducted research on 20 companies in Canada, with the finding that there is a valid, reliable, significant and substantive relationship between the dimensions of Intellectual Capital (Human capital, Custoner capital, Structural capital) and business 
performance. Previous research findings on the effect of human capital on structural capital have been shown to have a positive and significant effect (Bontis et al, 2000; Halim, 2010; Shih et al, 2010; Maditinos et al, 2010; Ahmadi et al, 2013; Mention and Bontis, 2013; Heriyanto and Hermawan 2015. Based on the description, then testing the hypothesis 2 which states that:

H2: Human capital has a positive effect on structural capital.

Effect of structural capital on financial performance. Structural capital is a means and infrastructure that supports employees to create optimum performance. This is because organizations with overall structural capital have a sportive culture that allows individuals to try new things, learn them, and are ready to fail (Bontis et al., 2000).

Based on resource based theory (RBT), structural capital, one of the elements of IC owned by the company, is able to create a competitive advantage of the company. If an organization is able to codify company knowledge and develop structural capital, for example, creating work through company tools, good work routines, good organizational culture, competitive advantage can be achieved. These advantages relatively result in higher company performance.

The results of other studies indicate that there is a positive relationship between intellectual capital and company performance (Pulic, 1998). In line with the results of Pulic's research (1998), Bontis (1998) found that there was a positive and significant relationship between structural capital and company performance. The same conclusion was also obtained from the research of Bontis et al (2000).

Empirical findings of the positive and significant influence of structural capital on performance, carried out by Bontis (1998); Bontis et al (2000); Cabrita et al (2009); Fotros and Beygi (2009); Shabarati et al (2010); Kamukama et al (2010); Yu et al (2010); Khalique et al (2011); Clarke et al (2011); Pertiwi et al (2013); Ahmadi et al (2013); Mention and Bontis (2013); Sayad and Pourmohammadi (2014); Aledwan (2014); Mohammadi (2014); Kalkan et al (2014); Untara and Mildawati (2014); Mushref (2014); Satiti and Fun (2014); Yaganeh et al (2014); Luminity (2016); Gogan et al (2016). Based on the description above, then testing the hypothesis 3 which states that:

H3: Structural capital has a positive effect on financial performance.

\section{METHODS OF RESEARCH}

This study uses a mixed research design, a research method that combines quantitative and qualitative research designs. The study began with a quantitative method based on the positivism philosophy, namely research aimed at testing general theories to produce findings that are specific through hypothesis testing related to the relationship between research variables.

Quantitative analysis based on multivariate analysis uses structural equation modeling or SEM (structural equation modeling) with a variance based or component based approach called PLS (partial least square). This research was conducted at BPR in the Province of Bali. The population in this study is conventional BPR in the Province of Bali, amounting to 136 BPR (Bank Indonesia, 2016). Determination of the size of the sample is done using the Slovin formula, which is a minimum sample of 60 BPR. The unit of analysis in this study is 60 leaders of each BPR.

The data collection techniques are carried out through: (1) questionnaire as a research instrument in a quantitative approach used to determine the effect of each dimension of intellectual capital on BPR financial performance. Respondents who will be given a questionnaire in the study are the leaders of the BPR; (2) Interview, is a method of collecting data where the researcher directly engages in dialogue with the respondent to explore information from the respondent. Interview technique is carried out if after analyzing there is still unclear information, an in depth interview will be conducted to obtain useful information. The aim of the interview technique is to get clear information and pictures of what the conditions in the field are like; (3) Documentation, is a method used to obtain data and information in the form of books, documents, written figures in the form of reports and 
information that supports research. The documentation used in this study includes BPR financial performance ratios consisting of Non-Performing Loans (NPLs), Minimum Capital Adequacy Obligations (KPMM), Loan to Deposit Ratio (LDR), Return on Assets (ROA), Operational Costs and Operating Income (NPL) BOPO) and Cash Ratio.

Based on the conceptual framework of the study, then in this study the exogenous variables are: human capital (X1), endogenous variables are: bank financial performance (Y2), intermediate variables or intervening variables are structural capital (Y1).

\section{RESULTS AND DISCUSSION}

Based on the results of the validity test it turns out that all instruments show that the correlation of each statement item score to the total score of each variable is significant at the $5 \%$ level $(0.05)$ meaning that all variables are valid. Based on the results of the reliability test it turns out that all instruments show a Cronbach's alpha value greater than 0.60 , meaning that all variables are reliable. Respondents with male gender have the largest percentage of $68 \%$ or 41 respondents and female respondents with a percentage of $32 \%$ or as many as 19 respondents. Respondents aged 51-60 years had the largest percentage, namely $50 \%$ or 30 respondents, followed by respondents with ages $41-50$ years and ages 20-30 years. Most respondents who have a Bachelor's education level with a percentage of $82 \%$ or 49 respondents, followed by S2 education with a percentage of $10 \%$ or 6 respondents, D3 education with a percentage of $8 \%$ or 5 respondents.

The convergent validity of the measurement model using reflective indicators is assessed based on the loading factor of the indicators that shape and reflect the construct. Based on the test results of the measurement model, it can be explained as follows: constructs of Culture, Intellectual Property and Process, all indicators have a loading factor above 0.7 , AVE is greater than 0.5 and communicality is more than 0.5 .

The measurement of discriminant validity of the measurement model is assessed based on cross loading measurements with the construct. If the cross loading value of each indicator of the variable concerned is greater than 0.70 , then the indicator is said to be valid. The analysis shows that the cross loading value of each indicator is more than 0.70 so that it is declared valid. Discriminant validity can also be tested by comparing the AVE square root value with the correlation value between latent constructs. The number on the diagonal line shows the value of the square root $A V E$ and the other value is the correlation between constructs. It is seen that the AVE square value is higher than the correlation value (latent variable correlation), it can be concluded that the model is valid because it meets Discriminant validity.

Table 1 - Comparison of AVE square root values with correlation values between latent constructs

\begin{tabular}{llll}
\hline & Financial Performance & Structural Capital & Human Capital \\
\hline Financial Performance & $\mathbf{0 , 8 3 9}$ & 0,274 & 0,254 \\
Structural Capital & 0,272 & $\mathbf{0 , 8 3 4}$ & 0,716 \\
Human Capital & 0,254 & 0,716 & $\mathbf{0 , 8 0 3}$ \\
\hline
\end{tabular}

Source: Data Analysis.

The variable reliability test is measured by two criteria, namely composite reliability and Cronbach's alpha of the block of indicators that measure variables. Variables are declared reliable if the composite reliability and Cronbach's alpha values are above 0.70 .

Table 2 - Cronbach's alpha Reliability Test Results and Composite reliability

\begin{tabular}{llll}
\hline & Cronbachs Alpha & Composite Reliability & Information \\
\hline Organizational Culture (Y11) & 0.826 & 0.896 & Reliabel \\
Intellectual Property (Y12) & 0.845 & 0.907 & Reliabel \\
Operational Process (Y13) & 0.885 & 0.929 & Reliabel \\
Financial Performance (Y4) & 0.915 & 0.934 & Reliabel \\
\hline
\end{tabular}

Source: Processed from Raw Data. 
Based on Table 2 it can be seen that all Cronbach's alpha values of each variable are greater than 0.70 . Thus it can be stated that the data in the study are reliable. Based on Table 2, it can be seen that all the Composite reliability values for each variable are greater than 0.70 . Thus it can be stated that the data in the study are reliable.

Human Capital in this study was constructed by eight dimensions, namely: Indra Brata (X11), Yama Brata (X12), Surya Brata (X13), Candra Brata (X14), Bayu Brata (X15), Kuwera Brata (X16), Waruna Brata (X17), and Agni Brata (X18). Testing of latent formative variables looks at the following outer weight analysis results:

Table 3 - Formative Human Weight Coefficient Outer Weight Variable

\begin{tabular}{cccccc}
\hline & Original Sample (O) & Sample Mean (M) & Standar Deviation (STDEV) & $\begin{array}{c}\text { T Statistics } \\
(\mid \mathrm{O} / \text { STDEV })\end{array}$ & P Values \\
\hline $\mathrm{X}_{11} \rightarrow \mathrm{X}_{1}$ & 0,129 & 0,129 & 0,017 & 7,666 & 0,000 \\
$\mathrm{X}_{12} \rightarrow \mathrm{X}_{1}$ & 0,141 & 0,142 & 0,009 & 16,447 & 0,000 \\
$\mathrm{X}_{13} \rightarrow \mathrm{X}_{1}$ & 0,139 & 0,138 & 0,013 & 10,393 & 0,000 \\
$\mathrm{X}_{14} \rightarrow \mathrm{X}_{1}$ & 0,135 & 0,136 & 0,011 & 12,181 & 0,000 \\
$\mathrm{X}_{15} \rightarrow \mathrm{X}_{1}$ & 0,135 & 0,134 & 0,012 & 11,365 & 0,000 \\
$\mathrm{X}_{16} \rightarrow \mathrm{X}_{1}$ & 0,135 & 0,135 & 0,010 & 13,399 & 0,000 \\
$\mathrm{X}_{17} \rightarrow \mathrm{X}_{1}$ & 0,146 & 0,145 & 0,013 & 11,528 & 0,000 \\
$\mathrm{X}_{18} \rightarrow \mathrm{X}_{1}$ & 0,146 & 0,147 & 0,011 & 13,678 & 0,000 \\
\hline
\end{tabular}

Source: Processed from Raw Data.

Based on table 3 the coefficient of latent outer weight of the formative variable Human capital is declared valid and is feasible to be continued to the level of structural model completion because it has a t-statistic value $>t$ calculated at a $5 \%$ confidence level $(\alpha)$ of 1.96. Outer weight values indicate significant at the $5 \%$ level, then the formative model is declared valid and is suitable for use in the research process.

Evaluation of structural models (inner models) aims to determine the good fit model, using the following methods:

$\mathrm{R} 2$ shows the strength of the influence caused by exogenous variables to endogenous variables, so that $\mathrm{R} 2$ can show the strength and weakness of a research model. According to Chin (2010) an R2 value of 0.67 is classified as strong, 0.33 is classified as a moderate model and 0.19 is classified as a weak model.

Table 4 - Distribution of R2 and R2 Adjusted values

\begin{tabular}{llll}
\hline Latent Variable & $\mathrm{R}^{2}$ & $\mathrm{R}^{2}$ Adjusted & Information \\
\hline Structural Capital (Y1) & 0,513 & 0,505 & Moderate \\
Financial Performance (Y2) & 0,492 & 0,455 & Moderate \\
Average & 0,502 & 0,480 & Moderate \\
\hline
\end{tabular}

Source: Processed from Raw Data.

The results found in Table 4, show the R2 Structural Capital value of 0.513 with the moderate category. Based on the three variables obtained an average value of R2 of 0.502 classified as a moderate model. The average value of R2 0.502 means that the human capital, structural capital, and financial performance models can be explained by $50.2 \%$ while the remaining $49.8 \%$ is explained by other variations outside the model. The adjusted R2 value is smaller than the $\mathrm{R} 2$ value distribution so it can be used as a clue that changes / expansion of the research model by including other latent variables are still possible.

Q-Square Predictive Relevance (Q2), which measures how well the observations produced by the 0-1 range model. Getting closer to 1 means that the model has better predictive ability.

$$
Q^{2}=1-\left\{\left(1-R^{2} Y_{1}\right)\left(1-R^{2} Y_{2}\right)\right\}=0,7526
$$

Q2 calculation results show a value of 0.7526 which means the model shows a very good observation that is $75.26 \%$, the relationship between variables can be explained by the 
model, the remaining $24.74 \%$ is another factor not included in the research model. This informs that the model formed in this study is very adequate to be forwarded to the level of testing the research hypothesis.

Table 5 - The direct influence of Asta Brata-based Human Capital, Structural capital, Relational capital, Social Capital and Financial Performance

\begin{tabular}{lllllll}
\hline Construct & Original Sample & Sample Mean & Standard Deviation & T Statistic & P Values & Info \\
\hline$X \rightarrow Y_{2}$ & 0,040 & 0,028 & 0,134 & 0,302 & 0,763 & Not Support \\
$X \rightarrow Y_{1}$ & 0,716 & 0,710 & 0,076 & 9,392 & 0,000 & Support \\
$Y_{1} \rightarrow Y_{2}$ & 0,505 & 0,500 & 0,146 & 3,451 & 0,001 & Support \\
\hline
\end{tabular}

Source: Data Processed, 2019.

The results of testing the direct effect based on the inner path model in the Partial Least Square (PLS) of the 3 hypotheses in this study, showed that there were two significant variables and one non-significant variable. Each variable can be explained as follows:

The results of the analysis of the inner path coefficient model in Partial Least Square (PLS) found that there was a direct influence of Asta Brata-based Human Capital variables on Financial Performance and obtained a positive path coefficient of 0.040 with a $p$-value of 0.763 . Because the $p$-value of 0.763 is greater than $0.05(0.763>0.05)$, there is not enough empirical evidence to accept the $\mathrm{H} 1$ hypothesis that Human Capital has a significant positive effect on financial performance $(\mathrm{H} 1$ is rejected), which means that however well Human Capital will have no effect to good or bad Financial Performance (Table 5).

The results of the analysis of the inner path coefficient model in Partial Least Square (Table 5) reveal that there is a direct influence of Asta Brata-based Human Capital variables on structural capital and a positive path coefficient value of 0.716 with a $p$-value of 0,000 is found. Because the p-value of 0,000 is less than $0.05(0,000<0.05)$, there is sufficient empirical evidence to accept the $\mathrm{H} 2$ hypothesis that Human Capital has a significant positive effect on Structural Capital (H2 accepted).

The results of the inner model path coefficient analysis in Partial Least Square (Table 5) reveal that there is a direct influence of the Structural Capital variable on Financial Performance and a positive path coefficient value of 0.505 with a p-value of 0.001 is obtained. Because the $p$-value of 0.001 is smaller than $0.05(0.001<0.05)$, there is sufficient empirical evidence to accept the H3 hypothesis that Structural Capital has a significant positive effect on financial performance (H3 accepted).

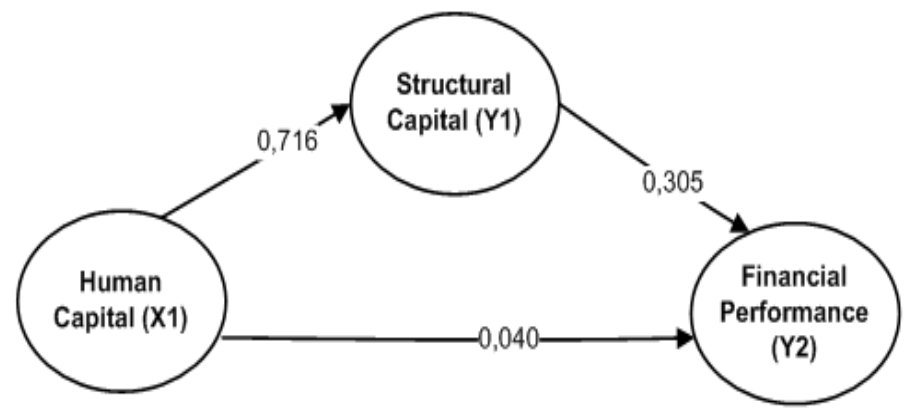

Figure 1 - Research Model

Table 6 - Indirect Relationship of Human Capital, Structural Capital, Relational Capital and Social Capital on Financial Performance

\begin{tabular}{|l|l|l|l|l|l|l|}
\hline No & Model & Path Coefficient & $T_{\text {test }}$ & $t_{\text {tabel }}$ & VAF & Information \\
\hline a & $\mathrm{X} \rightarrow \mathrm{Y}_{1}$ & 0,716 & 9,392 & $>1,96$ & 0,900 & a is significant, $\mathrm{b}$ is significant, \\
$\mathrm{b}$ & $\mathrm{Y}_{1} \rightarrow \mathrm{Y}_{2}$ & 0,505 & 3,451 & $>1,96$ & & $\mathrm{c}$ is not significant = full mediation \\
$\mathrm{c}$ & $\mathrm{X} \rightarrow \mathrm{Y}_{2}$ & 0,040 & 0,302 & $<1,96$ & & \\
\hline
\end{tabular}

Note: $X=$ Human Capital; $Y 1$ = Structural Capital; Y2 = Financial Performance.

Source: Data processed, 2019 
This test is to see the role of structural capital as a mediator of financial performance. Testing the role of mediation based on the concept of Hair et al (2013) through testing the Variance Accounted For (VAF) coefficient. Testing the role of structural capital, on financial performance can be seen in Table 6.

\section{DISCUSSION OF RESULTS}

The Influence of Human Capital on Financial Performance. The results of this study found that human capital had no significant positive effect on financial performance. The magnitude of the effect of human capital on Financial Performance is $4 \%$. The relationship between these two variables is not yet supported by empirical data, this indicates that Human Capital based on Asta Brata is unable to explain variations in changes in BPR financial performance in the Province of Bali. Thus, Human Capital (Asta Brata's high leadership) does not guarantee high BPR Financial Performance in the Province of Bali.

Explanation of the cause of insignificant Human Capital on BPR Financial Performance in Bali is an indication that the use of physical and financial assets still dominates to contribute to financial performance. In addition, the dimensions of Asta Brata's leadership have not been able to be fully implemented by the leadership of the BPR in an effort to improve the BPR's financial performance. Another cause of the insignificant influence of Asta Brata-based Human Capital on Financial Performance is due to differences in measurement concepts and indicators. Human Capital in this study was formed from the dimensions taken from the values of Asta Brata (Hinduism) Leadership, while the concept of measuring indicators and Financial Performance was not formed from the values of Hinduism.

The findings of this study are interesting considering that there has not been any previous research that examines the relationship of Human Capital which is explained by the concept of Asta Brata's leadership on Financial Performance. The majority of previous studies examined the effect of Human Capital as explained by employee perspectives on company performance. The findings of this study are expected to provide a more comprehensive understanding in the study of Human Capital with the local Balinese concept of Asta Brata leadership. The pattern of leadership adopted by the leaders of the BPR of the Province of Bali has basically adopted the values contained in the Asta Brata concept.

When associated with the concept of Human Capital in general, the results of this study are in line with the results of research conducted by Cabrita et al (2009) which found that Human Capital had a significant positive effect on bank business performance in Portugal. Nasih (2010) who conducted a study of 114 banks in Indonesia, found that human capital had no significant effect on financial performance which was proxied by fee-based income. Gholami and Sabetnia (2015) conducted a study of 75 financial staff at Yasooj University of Medical Science with the results of the research that Human Capital had no significant effect on Financial Performance at Yasooj University of Medical Science, then Vakilifard and Rasouli (2013) conducted a study of 108 drug companies listed on the Tehran Stock Exchange with the results of the Human Capital research have no significant positive effect on income smoothing and stock returns. The conformity of the results of previous studies with this research although the results of the research are the same but the objects and measurements are different, the results of this study enrich the findings of previous research.

The results of this study are not in accordance with what was studied by Fatoki (2011) who found that human capital had a significant positive effect on the performance of SMEs in South Africa. Khalique and lqbal (2014) revealed that Human Capital had a significant positive effect on the performance of franchise restaurants in Kulim, Kedah, Malaysia. Felicio et al (2014) proved that Human Capital with indicators of knowledge, experience, professional proficiency and cognitive ability had a significant positive effect on the performance of SMEs in Portugal.

Effects of Human Capital on Structural Capital. This study found that there was a significant positive effect on Human Capital on Structural Capital. The magnitude of the influence of Human Capital on Structural Capital is $71.6 \%$, meaning that the better the 
application of Human Capital through the leadership of Asta Brata will further enhance Structural Capital.

The findings of this study are interesting given that there has not been any previous research that examines the relationship of Human Capital that is explained by the concept of Asta Brata's leadership towards Structural Capital. The majority of previous studies examined the effect of Human Capital as explained by employee perspectives on Structural Capital. The findings of this study are expected to be able to provide a more comprehensive understanding in the study of Human Capital with the local Balinese concept of Asta Brata leadership.

When associated with the concept of Human Capital in general, the results of this study are in line with the results of research conducted by Bontis et al (2000) finding that human capital has a significant positive effect on structural capital in non-service companies in Malaysia. Moon and Kym (2006) state that human capital has a significant effect on structural capital. Cabrita et al (2009) states that human capital has a significant positive effect on structural capital. Halim (2010) on 57 SMEs in France, Germany, Poland, Slovenia and Spain who found that the correlation of human capital to structural capital was very strong (correlation of 0.88). Maditinos et al (2010) conducted research on 47 service companies and 72 non-service companies on the Greek Stock Exchange, stating that human capital had a significant positive effect on structural capital. Mention and Bontis (2013) state that human capital has a significant positive effect on structural capital in 213 banks in Luxemberg and Belgium. Mumtaz and Abbas (2014) conducted a study at a private university in Pakistan with the results of human capital research having a significant positive effect on structural capital.

This finding does not support the results of a study conducted by Bontis et al (2000) who found that human capital had a non-significant positive effect on structural capital in service companies in Malaysia. Pertiwi et al (2013) found that human capital had a significant positive effect on structural capital in the manufacturing industry in Indonesia.

Effect of Structural Capital on Financial Performance. This study found that there was a significant positive influence on Structural Capital on Financial Performance, meaning that if BPR employees wanted to improve their financial performance, they could maximize their Structural Capital through the dimensions of organizational culture (with indicators understanding vision, mission and motto; understanding systems and functions; practices operational / knowledge sharing), dimensions of intellectual property (with indicators of competitive advantage, employees as intellectual assets, having a database of information systems), as well as dimensions of operational processes (with indicators of good organizational structure, process efficiency, knowledge / information resources). The magnitude of the influence of Structural Capital on Financial Performance is 50.5\%, meaning that the better application of Structural Capital will improve Financial Performance.

The results of this study are in line with the results of research by Bontis et al (2000) in service and non-service companies in Malaysia, Maditinos (2010) who conducted research on 47 service companies and 72 non-service companies in Greece, Yaganeh et al (2014) who conducted research to insurance companies in Iran.

The results of this study do not support the results of research conducted by Mention and Bontis (2013) states that structural capital is not a significant positive effect on the performance of 213 banks in Luxemberg and Belgium. Vakilifard and Rasuoli (2013) who conducted research on drug companies listed on the Tehran Stock Exchange, found that structural capital had no significant positive effect on income smoothing and stock returns.

Ozkan et al (2016) who conducted research on 44 banks in Turkey with the results of structural capital efficiency (SCE) research did not have a significant effect on bank financial performance (ROE).

The Role of Structural Capital Mediates the Effect of Human Capital on Financial Performance. Statistical test results prove that Human Capital has an influence on Structural Capital, with an interaction effect of 0.716 while the interaction effect of the effect of Structural Capital on Financial Performance is 0.505 and the effect of Human Capital on Financial Performance is 0.040 (not significant). Because the impact on Human Capital on 
Financial Performance is insignificant, the results of this study prove that Human Capital cannot influence Financial Performance without going through Structural Capital.

Improved Financial Performance cannot be done by Human Capital and the results of this study also confirm the important role of Human Capital in implementing Asta Brata's leadership to improve Structural Capital and the important role of Structural Capital in improving Financial Performance.

The results of this study are in line with the results of Bontis (1998) research, namely the diamond specification model. Bontis Research (1998) does not link human capital with business performance. But linking human capital with structural capital, which is then both associated with business performance. This means that human capital can affect business performance only through structural capital. The results of this study also support the results of research Cabrita et al (2009) which states that human capital does not have a significant positive effect on bank business performance in Portugal and structural capital has a significant positive effect on bank business performance in Portugal.

The implication of this research is that without the support of organizational resources, individuals cannot do anything with their ideas. Organizations must also support and foster intelligent individuals to share human resources through organizational learning and form a culture that promotes reciprocal relations between their members. Therefore, structural capital is the infrastructure that supports people in organizations to exploit their intellectual potential, which shows that structural capital must be designed to maximize intellectual output.

By finding the full mediation role of Structural Capital in testing the role of Human Capital on Financial Performance, we've concluded that to improve financial performance, Structural Capital is the only strategic path that must be taken. This research yields important findings from the RBV context that BPR must meet a good and rigid organizational structure.

The results of this study is developing the concept of Human Capital based on local cultural values contained in the concepts of Asta Brata Leadership (Indra Brata, Yama Brata, Surya Brata, Candra Brata, Bayu Brata, Kuwera Brata, Waruna Brata and Agni Brata). The results of this study provide an empirical contribution to the role of Structural Capital in mediating Asta Brata-based Human Capital on the financial performance of BPRs in Bali Province.

The practical implications of the research findings are expected to be implemented and to improve financial performance and raise the image of rural banks in the province of Bali. The implementation of Intellectual Capital correctly and appropriately will benefit the Rural Bank of Bali (BPR), as input in the form of information about the bank's intellectual assets and the reference for managing Intellectual Capital in making strategic decisions and efforts to achieve effective effective business performance. The bank's internal process in the form of determining funding policies, is focused on managing and maximizing the empowerment of human capital and structural capital to support the operational / internal processes of the bank so that improvements in financial performance can be realized. Perbarindo Bali and the Financial Services Authority (OJK) are expected to be useful as a reference and consideration in strategic decision making, policy regulation related to the relevance of banking performance evaluation methods (bank health) by including Intellectual Capital to strengthen the accuracy of bank performance measurements to be more effective and applicable.

Some of the limitations and weaknesses of this study are as follows: Behavioral or behavioral research is vulnerable to be biased, so it is needed to be tested again in the future. The results cannot be disputed because it is only done in the banking sector, namely BPR, so a comparative test is needed between BPRs with commercial banks, cooperatives or LPDs in Bali. This study only examines the interrelationship of the role of the components of Intellectual Capital: Human Capital (leadership of Asta Brata), Structural Capital, Relational Capital and Social Capital on Financial Performance, but has not related to the performance of bank services and customer satisfaction. Therefore further research is needed in order to find a concept that is more comprehensive, more relevant to certain industries and specific to the banking service industry. 


\section{CONCLUSION AND SUGGESTIONS}

Human capital has no significant effect on the financial performance of Rural Credit Banks in Bali Province. This result means that the implementation of Asta Brata-based Human Capital (Indra Brata, Yama Brata, Surya Brata, Candra Brata, Bayu Brata, Kuwera Brata, Waruna Brata and Agni Brata) is not able to improve the financial performance of Rural Credit Banks in Bali Province. Human capital has a significant positive effect on structural capital in the Rural Credit Bank in Bali Province. These results mean that the application of Human Capital through Asta Brata leadership (Indra Brata, Yama Brata, Surya Brata, Candra Brata, Bayu Brata, Kuwera Brata, Waruna Brata and Agni Brata) is getting better, able to increase Structural Capital as measured by organizational culture dimensions, intellectual property and operational processes. Structural capital has a significant positive effect on the financial performance of Rural Credit Banks in Bali Province. This result means that the application of Structural capital is getting better, able to improve the financial performance of BPR as measured by the Minimum Capital Requirement (KPMM); Cash ratio (liquid assets adequacy ratio), Loan to Deposit Ratio (LDR); Return on Assets (ROA); Operational Costs Operating Income (BOPO) and Non Performing Loans (NPL). Structural capital is able to fully mediate the influence of human capital on the financial performance of Rural Credit Banks in Bali. This result means that the application of Human Capital through Asta Brata leadership (Indra Brata, Yama Brata, Surya Brata, Candra Brata, Bayu Brata, Kuwera Brata, Waruna Brata and Agni Brata) is able to improve BPR financial performance through Structural Capital measured by cultural dimensions organization, intellectual property and operational processes.

Based on the limitations of the research, the suggestion that can be given is that further research needs to be re-tested in the future because behavior or behavioral research is vulnerable to the effects of bias. Further research needs to be carried out a comparative test between BPRs with commercial banks, cooperatives or LPD in Bali so that it can be generalized. Further research can link with bank service performance and customer satisfaction in order to find a more comprehensive, more relevant and specific concept for the banking service industry.

\section{REFERENCES}

1. Ahmadi, Ali Akbar., Ahmadi, Freyedon., and Shakeri, Shaghayegh. 2013. The survey of relationship between Intellectual capital (IC) and Organizational performance (OP) within the National Iranian South Oil Company. European Journal of Business Management. Vol. 1. No. 1. Pp. $12-28$.

2. Aledwan, Baker. 2014. The Impact Of Basic Components Of Intellectual Capital On The Profitability Of Jordanian Commercial Banks (2007- 2012). European Scientific Journal. vol.10, No.28.

3. Andriessen, D. 2004. IC valuation and measurement: classifying the state of the art. Journal of Intellectual Capital. Vol. 5. No. 2. Pp. 230-242.

4. As'ad, Moh., Anggoro, Wahyu Jati., \& Virdanianty, Mariana. 2011. Studi Eksplorasi Konstrak Kepemimpinan Model Jawa: Asta Brata. Jurnal Psikologi. Vol. 38. No. 2. Pp. $228-239$

5. Asiaei, Kaveh and Jusoh, Ruzita. 2015. A multidimensional view of intellectual capital: the impact on organizational performance, Management Decision, Vol. 53. No. 3. Pp. 668 $-697$.

6. Bank Indonesia. 2016. Statistik Keuangan Daerah Provinsi Bali. Vol. 16. No. 06.

7. Barney, J. 1991. Firm resources and sustained competitive advantage. Journal of Management. Vol.17. No. 1. Pp. 99-120.

8. Bontis, Nick. 1998. Intellectual capital: an exploratory study that develops measure and models. Journal Management Decision. Vol. 36. No. 2. Pp. 63-76.

9. Bontis Michael, N. G., Chua Chong Keow, W., \& Richardson, S. 2000. IC in Malaysian industries Intellectual capital and business performance in Malaysian industries. Journal 
of Intellectual Capital. Vol. 1. No. 1. Pp. 85-100.

10. Brooking, A. 1996. "Intellectual Capital-Core Asset for the Third Millenium Enterprise". International Thomson Business Press, London. Vol. 8 No. 12-13, pp. 76.

11. Cabrita, Maria do Rosario., Machado, Virgilio Cruz., Grilo, Antonio. 2009. Creating Value for Intellectual Capital in Portuguese Banking Institutons. Lusada. International Journal of Engineering and Industrial Management. No. 1. Pp. 231-251.

12. Chen, Chung-Jen., Liu, Tsung-Chi., Chu, Mo-An., Hsiao, Yung-Chang. 2014. Intellectual capital and new product development. Journal of Engineering and Technology Management. No. 33. Pp. 154-173.

13. Chin, W. W. 2010. How to Write Up and Report PLS Analyses. In: Handbook of Partial Least Squares: Concepts, Methods and Application, Vinzi, V.E., W.W. Chin, J Henseler and H. Wang (Eds.). Springer, New York, USA., ISBN-13:9783540328254, pp: 655-690.

14. Clarke, M., Seng, D., \& Whiting, R. H. 2011. Intellectual capital and firm performance in Australia. Journal of Intellectual Capital. Vol. 12. No. 4. Pp. 505-530.

15. Christa, Usup Riassy. 2011. "Pengaruh Human Capital, Structural Capital Relational Capital Terhadap Kinerja Layanan Bank and Kepuasan Pelanggan (Studi pada Industri Jasa Bankj Umum di Kalteng)" Disertasi. Program Doktor IImu Manajemen Fakultas Ekonomi and Bisnis Universitas Brawijaya, Malang.

16. Dasi Astawa, I Nengah; Sedana, Gede. 2017. Kearifan Lokal Bali and Pembangunan Ekonomi. Suatu Model Pembangunan Ekonomi Bali Berkelanjutan. Denpasar: Pustaka Larasan.

17. Dharmanegara, Ida Bagus Agung; Sudarma, Made; Noermijati; Solimun. 2013. Mediation of Tri Hita Karana Organizational Culture in Effect of Spiritual Intelligence and Asta Brata Leadership on Employee Performance. Interdisciplinary Journal of Contemporary Research in Business, 5(6): 475-486.

18. Fatoki, O. 2011. The impact of human, social and financial capital on the performance of small and medium-sized enterprises (SMEs) in South Africa. Journal of Social Sciences, 29(3): 193-204.

19. Felicio, J. Augusto., Couto, Eduardo., Caiado, Jorge. 2014. Human capital, social capital and organizational performance. Management Decision. Vol. 52 No. 2. Pp. 350-364.

20. Ferrie, F \& McKenzie, P. 2004. Managing the new Performance Drivers: Information, Resources and Basic Steps to Self-Evaluation. http://www.education.monash.edu.au/centres/ceet/docs/otherpapers/ferriozickit.pdf.

21. Fisher, J.E, 1998. Contingency Theory, Management Control System and Firm Outcomes: Past Result And Future Directions. Behavioral Research in Accounting. Vol. 10, pp. 48-63.

22. Fotros, Mohammad Hasan \& Beygi, Tooraj. 2009. Assessing the Privatization of Iranian Banking Industry: An Intellectual Capital Performance Perspective. International Conference on Intellectual Capital Management. Publishers Zanjan Scince and Technology Park - Institute for Advanced Studies in Basic Sciences (IASBS).

23. Gholami, Abdolkhalegh \& Sabetnia, Masooud. 2015. Identifying and Ranking of the Components of Intellectual Capital Management and Their Impact on Financial Performance of Yasooj University of Medical Sciences. Jurnal UMP Social Sciences and Technology Management. Vol. 3, Issue. 3.

24. Gogan, Luminita Maria., Artene, Alin., Sarca, loana \& Draghici, Anca. 2016. The Impact of Intellectual Capital on Organizational Performance. Procedia - Social and Behavioral Sciences 221. Pp. $194-202$.

25. Hair, J.F., Ringle, C.M. and Sarstedt, M. 2013. Partial Least Squares Structural Equation Modeling: Rigorous Applications, Better Results and Higher Acceptance. Long Range Planning, 46. Pp. 1-12.

26. Halim, Siana. 2010. Statistical analysis on the intellectual capital statement", Journal of Intellectual Capital, Vol. 11 Iss 1 pp. 61 - 73

27. Hariyanto, Wiwit; Hermawan, Sigit. 2015. Pengaruh Intellectual Capital Terhadap Business Performance and Competitive Advantage pada Perusahaan Farm di Jawa Timur. Simposium Nasional Akuntansi 18. Universitas Sumatera Utara, Medan 16-19 
September 2015. Diunduh dari web: Centro Multi Akuntansi.

28. Hashim, Maryam Jameelah; Osman, Idris; Alhabshi, Syed Musa. 2015. Effect of Intellectual Capital on Organizational Performance. Procedia - Social and Behavioral Sciences. $207-214$.

29. Iswachidah. 2012. Kepemimpinan bupati prinsip asta brata sikap kenegarawanan kepemimpinan modern. Jurnal Pendidikan Kewarganegaraan Universitas Negeri Malang Vol.1, No.1:1-16.

30. Kalkan, Adnan., Bozkurt, Özlem Çetinkaya., Arman, Mutlu. 2014. The impacts of intellectual capital, innovation and organizational strategy on firm performance. Procedia - Social and Behavioral Sciences. Vol. 150, Pp: 700 - 707.

31. Kamukama, Nixon., Ahiauzu, Augustine \& Ntayi, Joseph M. 2010. Intellectual capital and financial performance in uganda's microfinance institutions. African Journal of Accounting, Economics, Finance and Banking Research Vol.6.No.6.

32. Kaplan, R, S. 2010. Conceptual Foundation of the Balanced Scorecard. Harvard Business School, 1-36.

33. Kariyadi, I Wayan. 2013. Rekonstruksi Kepemimpinan Dalam Nilai-nilai Ajaran Asta Brata and Politik Multikultur Masyarakat Global. Shopia Dharma, Volume I Edisi 1 Nomor 1: 107-120.

34. Kartono, Kartini. 2014. Pemimpin and Kepemimpinan: Apakah Kepemimpinan Abnormal itu? Jakarta: Rajawali Pers.

35. Khalique, M., Nassir Bin Shaari, J. A., Hassan, A., Isa, M., Ageel, A., Sarawak, M., \& Student, P. 2011. Relationship of Intellectual Capital With The Organizational Performance of Pharmaceutical Companies in Pakistan. Australian Journal of Basic and Applied Sciences, 5(12): 1964-1969.

36. Khalique, Muhammad \& Iqbal, Chaudhary Zafar. 2014. Intellectual Capital in Fast Food Franchise Restaurants of Kedah Malaysia. International Management Accounting Conference 7.

37. Luminitas Maria Gogan, Alin Artene, loana Saria, Anca Draghici. 2016. The Impact of Intellectual on Organizational Performance. Procedia-Social and Behavioral Sciences 221: 194-202.

38. Maditinos, Dimitrios., Ševic, Željko \& Tsairidis, Charalampos. 2010. Intellectual Capital and Business Performance: An Empirical Study for the Greek Listed Companies. European Research Studies. Volume XIII, Issue (3), pp: 145-167.

39. Mayo, Andrew. 2000. The role of employee development in the growth of intellectual capital, Personnel Review, Vol. 29 Iss 4 pp. $521-533$.

40. Mention, Anne-Laure \& Bontis, Nick. 2013. Intellectual capital and performance within the banking sector of Luxembourg and Belgium. Journal of Intellectual Capital. 14 (2): 286309.

41. Mohammadi, Roohollah., Sherafati, Mahshid \& Ismail, Mohd Nor Bin. 2014. Factors Affecting Intellectual Capital And Its Role In Financial Performance Of Organization. Indian J.Sci.Res. 5 (1): 314-320.

42. Moon, Y. J., \& Kym, H. G. 2006. A Model for the Value of Intellectual Capital. Canadian Journal of Administrative Sciences (Canadian Journal of Administrative Sciences), 23(3): 253-269.

43. Mumtaz, Sumia \& Abbas, Qaisar. 2014. An Empirical Investigation of Intellectual Capital Affecting the Performance: A Case of Private Universities in Pakistan. World Applied Sciences Journal. 32 (7): 1460-1467.

44. Mushref, Abbas Mezeal. 2014. The moderator role of organizational culture between intellectual capital and business performance: An empirical study in Iraqi industry. Net Journal of Social Sciences. Vol. 2(3), pp. 82-91.

45. Nasih, Mohamad. 2010. Intellectual Capital and Kinerja Perusahaan Perbankan Di Indonesia. Majalah Ekonomi Tahun XX, No. 2. Pp. 181-190.

46. Penrose, E.T. 1959. "The Theory of the Growth of the Firm". Basil Blackwell \& Mott Ltd. Great Britain.

47. Pertiwi, D., Katili, P. B., \& Anggraeni, S. K. 2013. Analisa Hubungan Intellectual Capital 
Terhadap Business Performance pada Industri Manufaktur. Jurnal Teknik Industri, 1(3): 265-271.

48. Pulic, A. 1998. Measuring the performance of intellectual potential in knowledge economy. Paper presented at the 2nd McMaster Word Congress on Measuring and Managing Intellectual Capital by the Austrian Team for Intellectual Potential.

49. Ritonga, Kirmizi; Andriyanie, Jessica. 2011. Pengaruh Modal Intelektual Terhadap Kinerja Keuangan Perusahaan LQ45 yang Terdaftar di Bursa Efek Indonesia. Pekbis Jurnal. Vol. 3. No. 2. Pp. 467-481.

50. Sangkala. 2006. Knowledge Management. Jakarta: Kharisma Putra Utama Offset.

51. Satiti, Ajeng \& Asyik, Nur Fadjrih. 2013. Pengaruh Intellectual Capital Terhadap Kinerja Keuangan Perusahaan Asuransi. Jurnal Ilmu \& Riset Akuntansi. Vol. 2 No. 7.

52. Sayed, A., \& Pourmohammadi, R. 2014. Evaluating the relationship between intellectual capital and financial performance in Iranian biotechnological production companies. Vol. 4. No. 1. Pp. 168-173.

53. Sharabati, Abdel-Aziz Ahmad, Shawqi Naji Jawad, and Nick Bontis. 2010. Intellectual capital and business performance in the pharmaceutical sector of Jordan. Management decision. Vol. 48. No. 1. Pp. 105-131.

54. Shih, Kuang-Hsun., Chang, Chia-Jung., Lin, Binshan. 2010. Assessing knowledge creation and intellectual capital in banking industry. Journal of Intellectual Capital. Vol. 11 No. 1. Pp. 74-89.

55. Sidharta, Rai. 2009. Kepemimpinana Hindu Asta Brata and Nasehat Sri Rama Lainnya. Surabaya: Paramita.

56. Soheyli, F., Moeinaddin, M., \& Nayebzadeh, S. 2014. The Relationship between Components of Intellectual Capital and Performance of Yazd Tile Companies. International Journal of Academic Research in Accounting, Finance and Management Sciences. Vol. 4. No. 1. Pp. 319-330.

57. Stewart, T.A. 1997. The New Wealth of Organizations. Doubleday/Currency, New York, NY.

58. Suryaningsih, Ariati \& Januarti, Indira. 2012. Analisis Nilai Tambah Sebagai Indikator Modal Intelektual and Pengaruhnya Terhadap Kinerja Keuangan and Nilai Pasar Pada Perusahaan Manufaktur Yang Terdaftar Di Bursa Efek Indonesia. Diponegoro Journal Of Accounting. Volume 1, Nomor 1. Pp. 1-15

59. Titko, J., Skvarciany, V., \& Jurevičienè, D. 2015. Drivers of bank profitability: Case of Latvia and Lithuania. Intellectual Economics, 9(2), 120-129. https://doi.org/10.1016/j.intele.2016.02.003

60. Ulum, Ihyaul. 2008. Intellectual Capital Performance Sektor Perbankan di Indonesia, Jurnal Akuntansi and Keuangan. Vol. 10. No. 2. Pp. 77-84.

61. Untara, 2014. Pengaruh Intellectual Capital Terhadap Kinerja Keuangan Perusahaan Perbankan Yang Terdaftar Di Bei. Jurnal Ilmu \& Riset Akuntansi Vol. 3 No. 10.

62. Vakilifard, Hamidreza., Rasouli, Masoumeh Sadat. 2013. The Relationship Between Intellectual Capital And Income Smoothing And Stock Returns (Case in Medicinal Companies). Financial Assets and Investing, No. 2 (3): 28-42.

63. Wernerfelt, B. 1984. "A Resource-Based View of the Firm". Strategic Management Journal. Vol. 5, pp. 171-180.

64. Wirata, I Wayan. 2011. Kepemimpinan Universal Pada Era Globalisasi Dalam Konsep Hindu. GaneC Swara. Vol. 5 No.1. Pp. 92-99.

65. Yeganeh, M. V., Sharahi, B. Y., Mohammadi, E., \& Beigi, F. H. 2014. A Survey of the Relationship between Intellectual Capital and Performance of the Private Insurance Companies of Iran. Procedia - Social and Behavioral Sciences, 114: 699-705.

66. Yu, K.Y., Ng, H.T., Wong, W.K., Chu, S.K.W. \& Chan, K.H. 2010. An empirical study of the impact of intellectual capital performance on business performance. The 7th International Conference on Intellectual Capital, Knowledge Management \& Organisational Learning, The Hong Kong Polytechnic University, Hong Kong.

67. Yukl, G. 2010. Leadership in organization: 7th edition. New Jersey: Pearson Prenctice Hall. 